\title{
Frontogenesis and Variability in Denmark Strait and Its Influence on Overflow Water
}

\author{
Michael A. Spall, Robert S. Pickart, And Peigen Lin \\ Woods Hole Oceanographic Institution, Woods Hole, Massachusetts \\ WILKEN-JON VON APPEN \\ Alfred Wegener Institute Helmholtz Centre for Polar and Marine Research, Bremerhaven, Germany \\ DANA MASTROPOLE \\ Woods Hole Oceanographic Institution, Woods Hole, Massachusetts \\ H. VALDIMARSSON \\ Marine and Freshwater Research Institute, Reykjavik, Iceland \\ Thomas W. N. Haine And Mattia Almansi \\ The Johns Hopkins University, Baltimore, Maryland
}

(Manuscript received 25 February 2019, in final form 8 May 2019)

\begin{abstract}
A high-resolution numerical model, together with in situ and satellite observations, is used to explore the nature and dynamics of the dominant high-frequency (from one day to one week) variability in Denmark Strait. Mooring measurements in the center of the strait reveal that warm water "flooding events" occur, whereby the North Icelandic Irminger Current (NIIC) propagates offshore and advects subtropical-origin water northward through the deepest part of the sill. Two other types of mesoscale processes in Denmark Strait have been described previously in the literature, known as "boluses" and "pulses," associated with a raising and lowering of the overflow water interface. Our measurements reveal that flooding events occur in conjunction with especially pronounced pulses. The model indicates that the NIIC hydrographic front is maintained by a balance between frontogenesis by the large-scale flow and frontolysis by baroclinic instability. Specifically, the temperature and salinity tendency equations demonstrate that the eddies act to relax the front, while the mean flow acts to sharpen it. Furthermore, the model reveals that the two dense water processes-boluses and pulses (and hence flooding events) - are dynamically related to each other and tied to the meandering of the hydrographic front in the strait. Our study thus provides a general framework for interpreting the short-time-scale variability of Denmark Strait Overflow Water entering the Irminger Sea.
\end{abstract}

\section{Introduction}

Transformation of surface waters to dense overflow waters at high latitudes is a fundamental component of the Atlantic meridional overturning circulation (AMOC). Strong air-sea buoyancy forcing in the Nordic Seas converts the warm, subtropical-origin water to cold water that returns equatorward at depth. The newly ventilated dense water subsequently flows through gaps in the GreenlandScotland ridge, the largest of these overflows occurring in

\footnotetext{
Corresponding author: Michael A. Spall, mspall@whoi.edu
}

Denmark Strait (transport at the sill $3.2-3.5 \mathrm{~Sv} ; 1 \mathrm{~Sv} \equiv$ $10^{6} \mathrm{~m}^{-3} \mathrm{~s}^{-1}$; Harden et al. 2016; Jochumsen et al. 2017). As the Denmark Strait Overflow Water (DSOW) descends the continental slope into the Irminger Sea its transport nearly doubles due to entrainment of ambient water, forming the headwaters of the Deep Western Boundary Current (Dickson and Brown 1994). Identifying and diagnosing the dynamical processes that regulate the overflow in Denmark Strait is thus of key importance to improve our understanding of the functioning of the AMOC.

It has now been established that there are three pathways of dense water flowing into Denmark Strait: the 


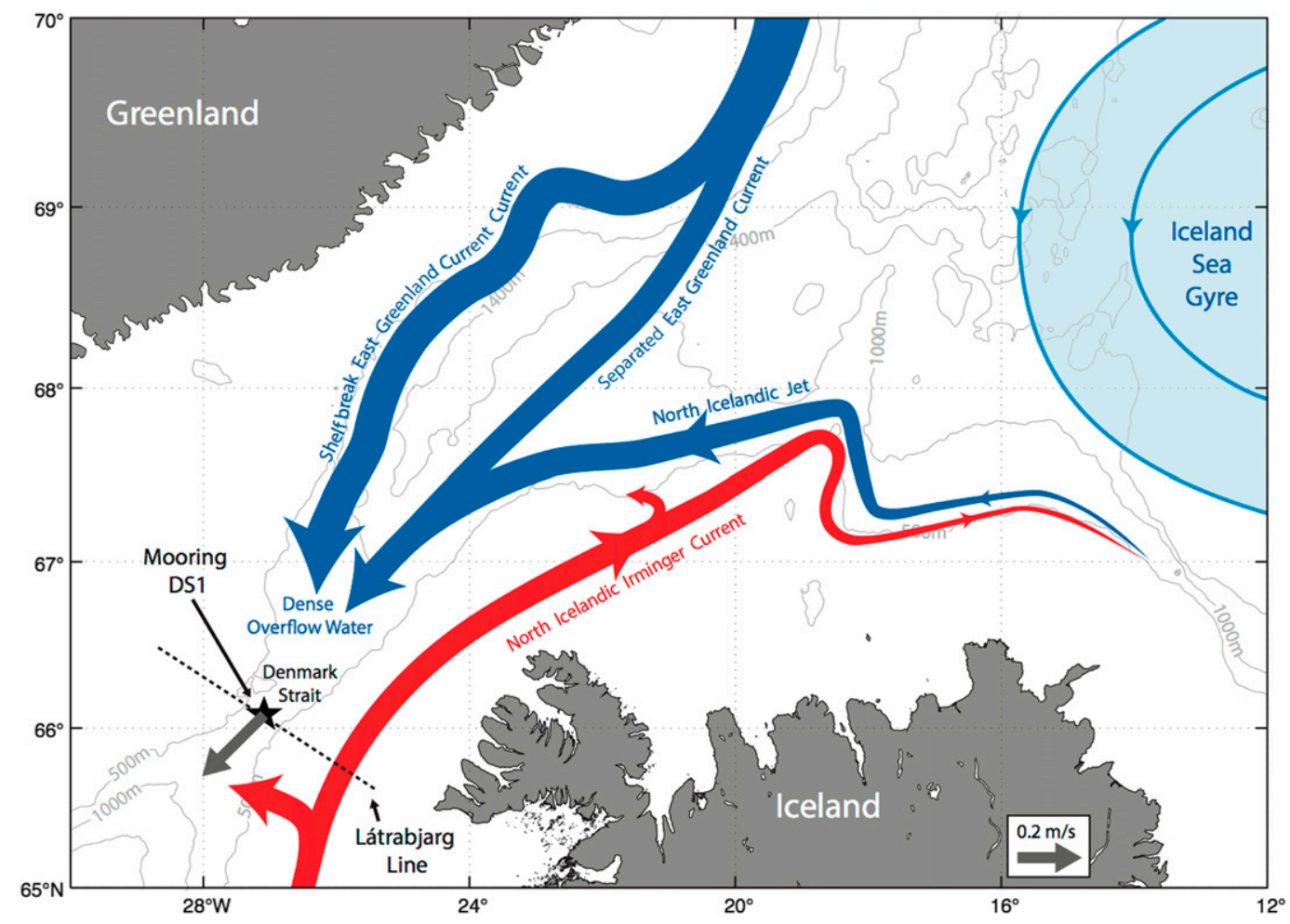

FIG. 1. Schematic circulation showing the three dense water pathways to Denmark Strait (blue lines) and subtropical inflow from the Irminger Sea (red line). The location of the DS1 mooring is marked by the star, and the Látrabjarg transect is indicated by the dashed line. The 10-yr mean flow vector from the DS1 mooring, averaged over the depth range from $400 \mathrm{~m}$ to bottom, is shown (see the key). The gray contours are the isobaths.

Shelfbreak East Greenland Current (EGC), the Separated EGC, and the North Icelandic Jet (NIJ, see Fig. 1). The first two currents advect mainly Atlantic-origin overflow water, which is the relatively warm and salty dense water transformed within the rim-current overturning loop of the Nordic Seas (Mauritzen 1996; Våge et al. 2011). The Separated EGC is an offshoot of the shelfbreak EGC that forms near a sharp bend in the bathymetry near $69^{\circ} \mathrm{N}$ (Våge et al. 2013). By contrast, the NIJ advects predominantly Arctic-origin overflow water that was transformed in the interior of the western Nordic Seas (Våge et al. 2011, 2015). This water is colder, fresher, and denser than the Atlantic-origin overflow water. As the NIJ approaches the strait it merges with the Separated EGC (Harden et al. 2016). The other major current in Denmark Strait is the northward-flowing North Icelandic Irminger Current (NIIC) which advects subtropical-origin water into the Iceland Sea (Fig. 1). It is believed that the NIIC and NIJ constitute the inflow and outflow, respectively, of a local overturning loop in the Iceland Sea (Våge et al. 2011; Pickart et al. 2017).

The transport of DSOW (the sum of the branches in Fig. 1) shows no long-term trend and displays little seasonality (Jochumsen et al. 2012, 2017). It has been argued that hydraulic control takes place in the strait, which helps set the mean transport (Whitehead et al. 1974; Whitehead 1989; Käse et al. 2003; Nikolopoulos et al. 2003). Whitehead (1989) used shipboard hydrographic data to evaluate the hydraulically derived volume flux, which gave a transport of $3.9 \mathrm{~Sv}$, in line with the recent mooring estimates noted above. In contrast to the steady nature of the overflow over seasons and years, the flow at the sill is found to vary strongly on short time scales of order 2-5 days (Aagaard and Malmberg 1978; Ross 1978; Macrander et al. 2007; Jochumsen et al. 2017). Earlier studies attributed these high-frequency fluctuations to baroclinic instability (Smith 1976), and fluctuations of a southward-flowing surface current in the strait (Fristedt et al. 1999).

Recent analyses of multiple years of hydrographic and velocity data in Denmark Strait have shed further light on the nature of the short-time-scale variability at the sill. Two different mesoscale processes have been described, which are referred to boluses and pulses. The former (which was first identified decades earlier; Cooper 1955) corresponds to the passage of a thick lens of cold, dense overflow water. Using a collection of over 100 occupations of the Látrabjarg transect across the Denmark 
Strait sill over a 23-yr period (see Fig. 1 for the location of the transect), Mastropole et al. (2017) found that boluses were present on $41 \%$ of the sections. The features are typically found on the western flank of the strait. Using 6 years of mooring data, von Appen et al. (2017) found that boluses are associated with cyclonic azimuthal circulation in the water above the overflow layer as they pass through the strait, although they do not appear to be isolated, coherent eddies. The overflow transport is enhanced when a bolus goes by, mainly due to the raising of the interface between the dense water and the ambient fluid above.

The second dominant mesoscale feature found in Denmark Strait is referred to as a pulse (these have only recently been identified; von Appen et al. 2017). In contrast to boluses, pulses correspond to a thinning and acceleration of the overflow layer. Furthermore, von Appen et al. (2017) determined that they are associated with an anticyclonic azimuthal flow in the water above the overflow layer. Using the same set of shipboard sections employed by Mastropole et al. (2017), it was demonstrated that the passage of a pulse is coincident with a westward migration of the NIIC hydrographic front throughout the water column. von Appen et al. (2017) speculated that there might be a dynamical connection between the deep pulses of dense water and the variability of the NIIC. As with boluses, the transport of overflow water is enhanced when a pulse occurs, except in this case it is due to the large increase in equatorward velocity of the DSOW which more than compensates the thinning of the layer. Based on the combination of shipboard and mooring data, von Appen et al. (2017) concluded that either a bolus or pulse passes through Denmark Strait on average every 2 days, which is of the correct time scale to account for the dominant high-frequency variability noted by the many previous studies.

Numerical simulations have also been used to investigate the energetic fluctuations in Denmark Strait. Käse et al. (2003) ran a model with an upstream reservoir of dense water (i.e., a "dam break" problem) to investigate the resulting flow through the strait. Eddies were generated along the path of the dense water which had similar characteristics to boluses. Spall and Price (1998) found that an outflow of dense and intermediate waters through the strait produced strong cyclones that were in general agreement with observations. The main driver of the explosive cyclogenesis was stretching of the intermediate layer above the overflow water. Almansi et al. (2017) analyzed a high-resolution general circulation model with realistic geometry and atmospheric forcing. The variability in Denmark Strait was found to be quite similar to that seen in the observations of Mastropole et al. (2017) and von Appen et al. (2017). In particular, both boluses and pulses were present in the model with similar characteristics and time-space scales. Consistent with the data, the boluses were cyclonic and the pulses were anticyclonic, and both features resulted in an increase in equatorward transport of overflow water. Almansi et al. (2017) also determined that sea surface height anomalies were centered upstream of the sill when boluses and pulses crossed the strait, which is consistent with baroclinic instability. It still remains to be determined, however, what the precise dynamics are of both types of features, and if they are related to each other.

In the present study we further investigate the nature of the high-frequency variability in Denmark Strait using a combination of in situ and satellite data together with a high-resolution numerical model [the same model employed by Almansi et al. (2017)]. First, we describe another mesoscale process that occurs in Denmark Strait which is referred to as a flooding event. During such an event, warm subtropical-origin water flows northward through the deepest part of the sill, associated with a westward migration of the NIIC. Next, using the different data sources, it is shown that the flooding events are in fact related to the previously described pulses. The numerical model is then used to explore the dominant variability in the strait, focusing on the role of the NIIC front; namely, the occurrence of frontogenesis and instability. In doing so, we demonstrate that the three types of DSOW variability-boluses, pulses, and flooding events-are tied together within a single dynamical framework. Our results thus provide insight regarding the time-dependent flux of overflow water into the Irminger Sea.

\section{Data and numerical model}

\section{a. In situ data}

The primary in situ data used in the study are from mooring DS1 deployed in Denmark Strait at the deepest part of the sill (Fig. 1). The mooring contains an RDI $75-\mathrm{KHz}$ upward-facing Long Ranger acoustic Doppler current profiler (ADCP) situated at $648 \mathrm{~m}$, roughly $8 \mathrm{~m}$ above the sea floor. Velocity was recorded every hour in $16-\mathrm{m}$ bins over the depth range $80-630 \mathrm{~m}$. The dominant tides were removed using the T_TIDE software package (Pawlowicz et al. 2002). It has been documented that in some years the DS1 ADCP underestimates the nearbottom velocity due to interference from side-lobe reflections (Jochumsen et al. 2017). However, this does not affect the results presented here as we are not concerned with the detailed structure of the near-bottom flow. In particular, the identification and characterization of the warm water flooding events in Denmark Strait are not 
qualitatively influenced by this. The same was true for the analysis of boluses and pulses carried out by von Appen et al. (2017). Here we consider the 10-yr time period from 2005 to 2015 (although there are no data for the 2006-07 deployment year). Velocities are rotated to the along-stream (positive $230^{\circ} \mathrm{T}$ toward the Irminger Sea, where ${ }^{\circ} \mathrm{T}$ is degrees true) and cross-stream (positive $140^{\circ} \mathrm{T}$ toward Iceland) directions. The along-stream direction is dictated by the long-term mean flow vector from DS1 (von Appen et al. 2017). We also use the data from the temperature sensor on the ADCP, which has a resolution of $0.1^{\circ} \mathrm{C}$ and accuracy of $0.4^{\circ} \mathrm{C}$. Comparisons with calibrated MicroCATs indicate that the accuracy of the ADCP thermistor is in fact better than this (D. Torres 2018, personal communication).

\section{b. Satellite data}

The along-track absolute dynamic topography (ADT) data used in the study were obtained from Copernicus Marine and Environment Monitoring Service (CMEMS, http://marine.copernicus.eu/), which provides the satellite altimetry product formerly distributed by Archiving Validation and Interpretation of Satellite Data in the Ocean (AVISO). The measurements were made by the Jason-1 satellite until October 2008, after which Jason-2 became operational. The along-track data have a spatial resolution of $12 \mathrm{~km}$, and, since Denmark Strait is near the latitude of the turning point of the satellite, the temporal resolution is roughly 2 days. We also use the daily gridded surface geostrophic velocity product from CMEMS which merges the multiple satellite altimeter measurements and has a horizontal resolution of $0.25^{\circ}$ in longitude and latitude. For sea surface temperature (SST) we employ MODIS Aqua Level 3 imagery with 9-km resolution (https://podaac.jpl.nasa.gov/). The time period considered for all datasets is 2006-15, which roughly corresponds to the time period of the DS1 mooring data used here.

\section{c. Numerical model description}

The numerical circulation model dataset used here is a high-resolution realistic run of the Massachusetts Institute of Technology General Circulation Model (MITgcm; Marshall et al. 1997). It is publicly available on the Johns Hopkins University SciServer system (http:// www.sciserver.org/integration/oceanography/). The model setup is explained in detail in Almansi et al. (2017), but is briefly described here. The model was run for 1 year (from September 2007 to August 2008) assuming hydrostatic balance, implementing a nonlinear formulation for the freesurface, and applying the nonlocal $K$-profile parameterization for vertical mixing. ERA-Interim (Dee et al. 2011) provides the atmospheric boundary conditions used to force the oceanic and sea ice components every $3 \mathrm{~h}$. The horizontal resolution is $2 \mathrm{~km}$ over the region of interest, the vertical resolution varies from $1 \mathrm{~m}$ at the surface to $15 \mathrm{~m}$ below a depth of $120 \mathrm{~m}$, and the numerical solutions have been stored every $6 \mathrm{~h}$. This high resolution is appropriate for studies, such as the present one, focusing on high-frequency mesoscale features.

\section{d. Model prior validation}

The model hydrography and circulation in Denmark Strait have been previously compared with available observations (Almansi et al. 2017). Overall, the model does an excellent job of capturing the major currents and water masses observed in Denmark Strait. Almansi et al. (2017) identified the subtropical-origin (Irminger) water, the recirculated Irminger water, and both types of overflow water (Arctic origin and Atlantic origin) in the model. The currents advecting these water masses to the strait are well captured by the model, and the simulated NIIC and DSOW velocities are similar to the measurements reported by Våge et al. (2011). The properties of the water masses mentioned above are consistent with the historical CTD data analyzed by Mastropole et al. (2017). The model does, however, appear to have a small bias in temperature affecting the density in the deep part of the water column. Specifically, while the isopycnal structure across the strait is very similar to that seen in observations, the measured overflow is slightly denser than the model overflow (the magnitude of density biases does not exceed $0.1 \mathrm{~kg} \mathrm{~m}^{-3}$, corresponding to a model warm bias of less than $1^{\circ} \mathrm{C}$ ).

\section{Warm water flooding events in Denmark Strait}

\section{a. Evolution of a composite event using the mooring data}

In line with previous studies, we define DSOW as water denser than $27.8 \mathrm{~kg} \mathrm{~m}^{-3}$ (Dickson and Brown 1994). In the mean, the dense water is banked against the western side of the trough separating the Iceland and Greenland shelf breaks as it flows through the strait (Fig. 2a). The $27.8 \mathrm{~kg} \mathrm{~m}^{-3}$ isopycnal rises $250 \mathrm{~m}$ from east to west, and the coldest, densest Arctic-origin overflow water is found at the bottom of the trough where the DS1 mooring is located. When boluses pass by, the interface can rise to within $200 \mathrm{~m}$ of the surface, associated with the thick lens of Arctic-origin water (Mastropole et al. 2017). By contrast, the interface deepens when pulses go by such that the DSOW layer can be less than $100 \mathrm{~m}$ thick (von Appen et al. 2017).

On occasion, much of the trough at Denmark Strait is filled with warm, subtropical origin water. An example is shown in Fig. 2b, where water warmer than $4^{\circ} \mathrm{C}$ occupies most of the Látrabjarg section, including the deepest 


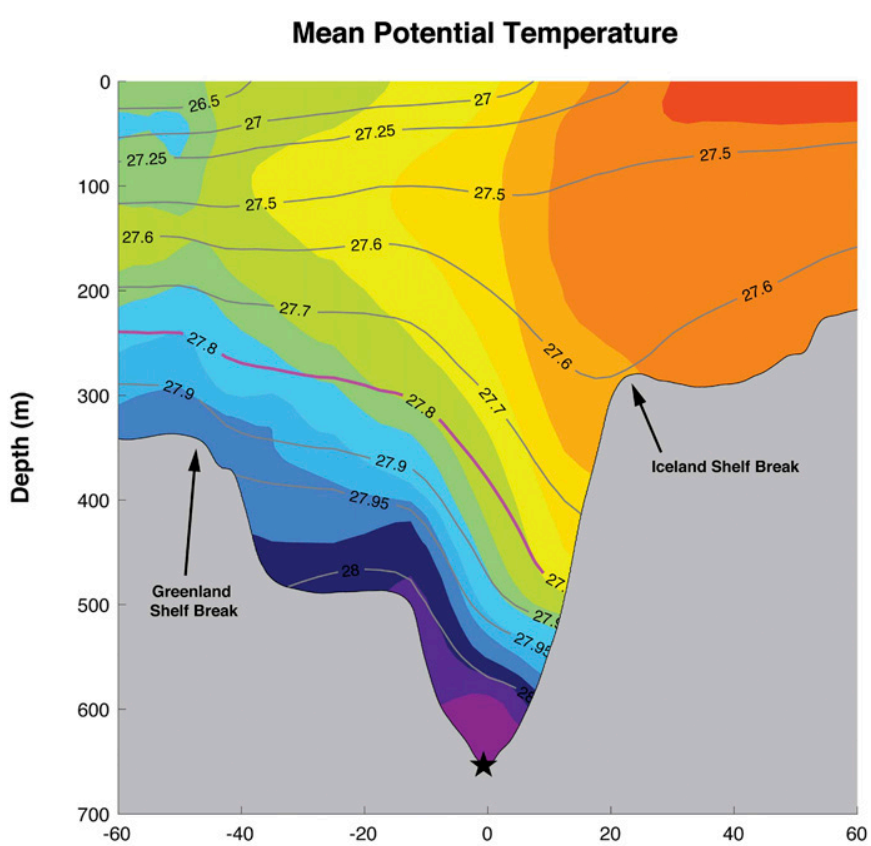

\section{Potential Temperature During Flooding Event}

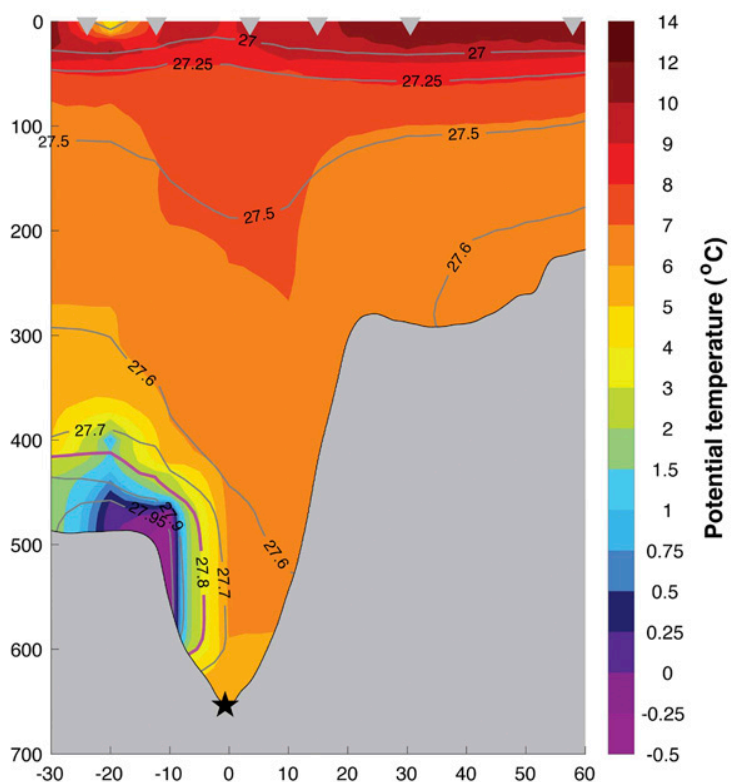

\section{Distance (km)}

FIG. 2. (a) The mean vertical section of potential temperature (color; ${ }^{\circ} \mathrm{C}$ ) overlain by potential density (contours; $\mathrm{kg} \mathrm{m}^{-3}$ ) at the Látrabjarg line across Denmark Strait from Mastropole et al. (2017) (see Fig. 1 for the location of the line). The $27.8 \mathrm{~kg} \mathrm{~m}^{-3}$ density contour, delimiting the DSOW layer, is highlighted by the thick magenta contour. The DS1 mooring is indicated by the black star. (b) The Látrabjarg section occupied on 11 Aug 2001, which captured a warm water flooding event in Denmark Strait. The CTD station positions are indicated along the top of the figure.

part of the sill. During this occupation of the line there was only a small amount of DSOW present. How often does this situation occur? For the collection of 111 shipboard sections considered by Mastropole et al. (2017) only a small number of realizations captured this state (the section shown in Fig. $2 b$ is the most pronounced example), suggesting that the condition is not common. To investigate this more definitively we considered 9 years of DS1 mooring data.

Using a graphical user interface (GUI) applied to the mooring data, we identified all of the instances in which the temperature at the bottom of the trough exceeded $1^{\circ} \mathrm{C}$. The majority of them $(>70 \%)$ were associated with northward flow through the strait. On occasion the
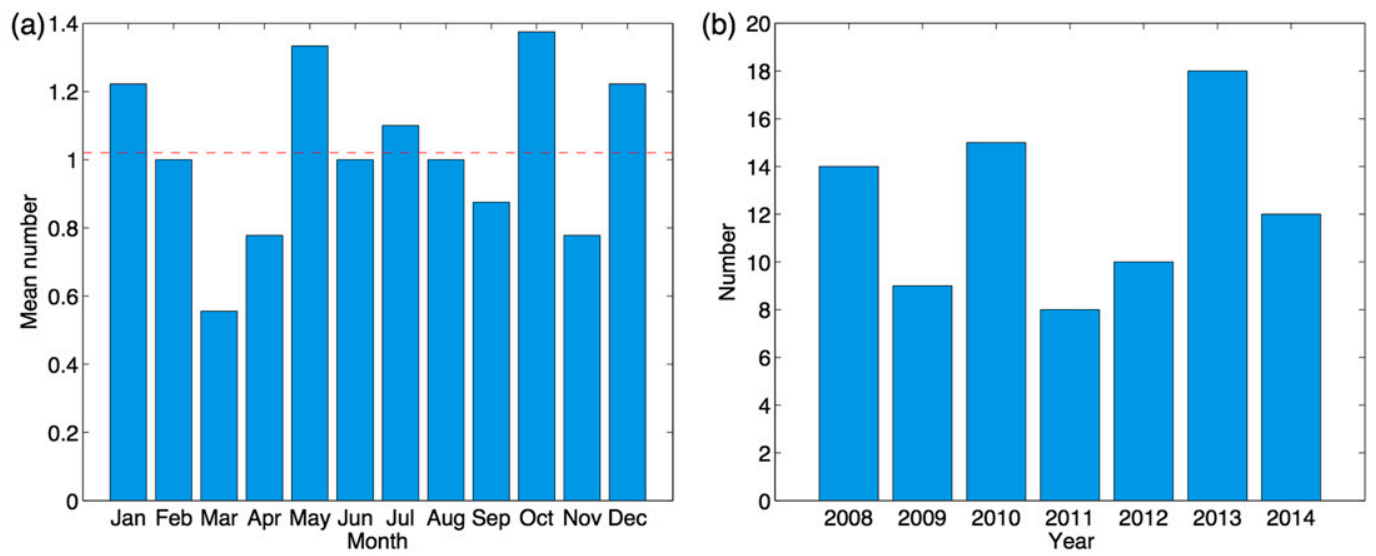

FIG. 3. (a) Average number of warm water flooding events per month in Denmark Strait using all 9 years of DS1 mooring data. The red line indicates the number of events per month when averaged over the year. (b) Number of events per year from 2008 to 2014 (the years in which the deployments lasted a full calendar year). 

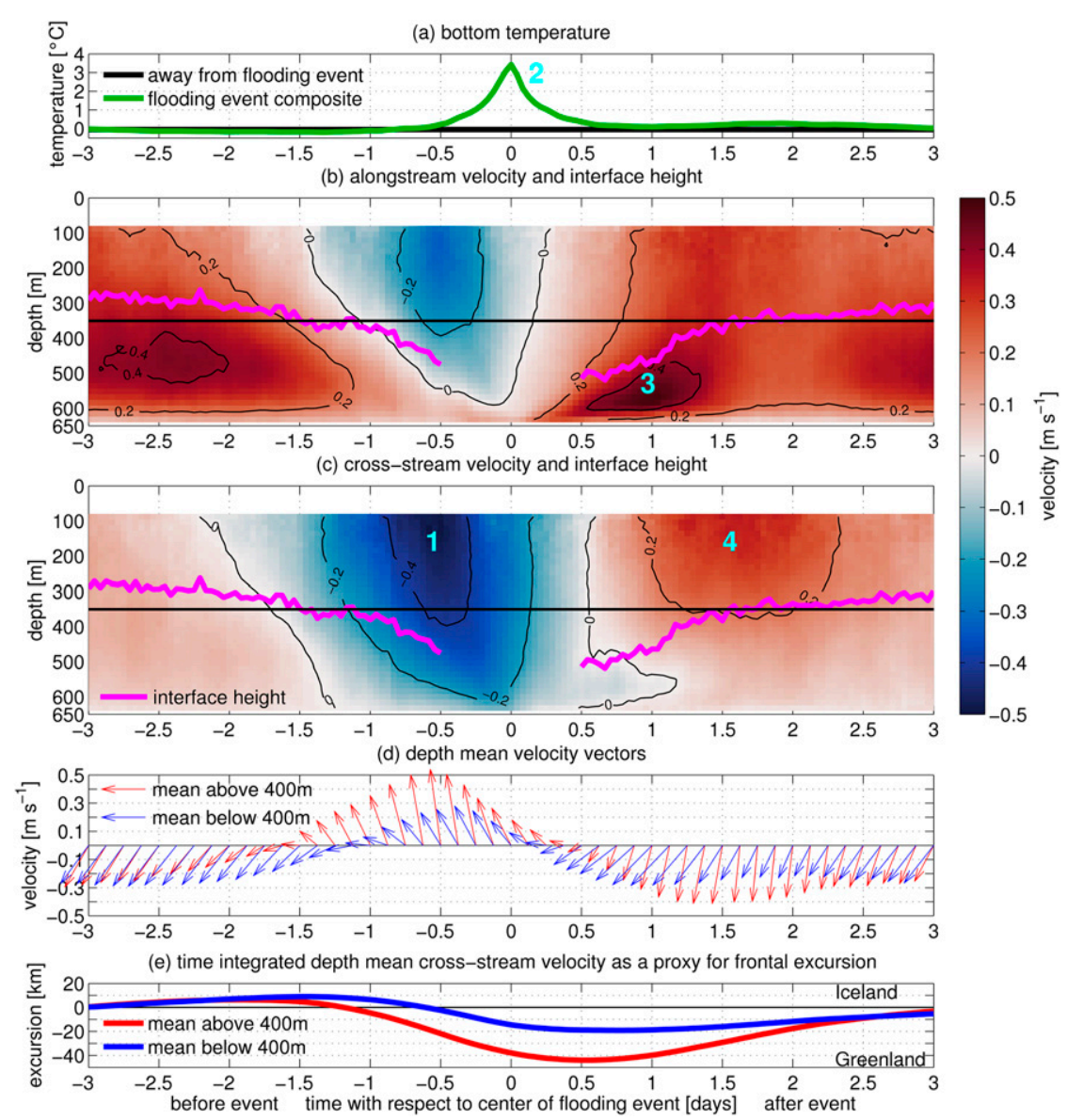

FIG. 4. Composite warm water flooding event constructed using the mooring data. (a) Bottom temperature (green curve; ${ }^{\circ} \mathrm{C}$ ). The value away from the flooding events is indicated by the black line. (b) Along-stream velocity $\left(\mathrm{m} \mathrm{s}^{-1}\right)$. The magenta line denotes the top of the overflow water layer; the black line indicates the value of this interface away from the flooding events. (c) Cross-stream velocity $\left(\mathrm{m} \mathrm{s}^{-1}\right)$. (d) Averaged velocity vectors (northward is upward) from $400 \mathrm{~m}$ to the bottom (blue) and from $400 \mathrm{~m}$ to the surface (red). (e) Time integrated depthaveraged cross-stream velocity for the two layers, as a proxy for frontal excursion. A negative excursion is toward Greenland. The sequence/timing of the composite flooding event is numbered in the different panels: 1) northwest flow toward Greenland, 2) bottom temperature peak, 3) equatorward pulse of overflow water, and 4) cross-streamflow toward Iceland.

temperature was warmer than $6^{\circ} \mathrm{C}$. We refer to this condition as a warm water flooding event; that is, when the bottom temperature is warmer than $1^{\circ} \mathrm{C}$ and the alongstreamflow reverses to the north. Over the 9 -yr record there were 151 such events-on average, one per month. There is no apparent seasonality or long term trend to the flooding events (Fig. 3).

The GUI revealed that there was a well-defined, consistent evolution associated with this process. To quantify this we constructed a composite average of all the events, aligning each one at the time of maximum temperature. Figure 4 shows the resulting composite time series of temperature and velocity over a \pm 3 -day period surrounding the peak temperature, which is defined as time $=0$. The top panel is bottom temperature, the next two panels are depth dependent along-stream and crossstream velocity. The fourth panel is the flow averaged over the approximate depth range of the DSOW layer, and that averaged in the water column above this. (The final panel is discussed below.)

Prior to the onset of the flooding event, the DSOW is flowing to the southwest as it does in the mean (see Fig. 1), and the bottom temperature is colder than $0^{\circ} \mathrm{C}$ corresponding to the Arctic-origin overflow water. Roughly a day before the peak of the event, the flow reverses to the northwest, reaching maximum strength $\sim 12 \mathrm{~h}$ before the temperature attains its highest value $\left(3.4^{\circ} \mathrm{C}\right.$ in the composite mean). Note that the northwest flow is surface-intensified, 


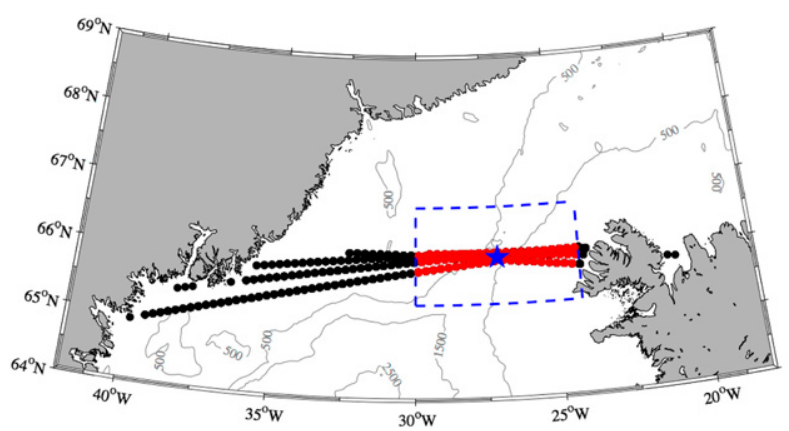

FIG. 5. Satellite tracks crossing Denmark Strait near the DS1 mooring site. The ADT data from the red portions of the tracks (within the dashed blue rectangle) were used to compute the surface geostrophic velocity for the composites of Fig. 6 a.

which suggests that it is the NIIC. As the temperature falls, the southwest flow of DSOW is established again. On average the events last 1.2 days, with the velocity signal leading the temperature signal.

\section{b. Sea surface signature of an event}

To shed further light on the nature of the flooding events, we analyzed the along-track ADT of the sea surface in the vicinity of Denmark Strait from CMEMS (see section $2 \mathrm{~b}$ ). There are four satellite tracks that cross the strait, passing almost directly over the DS1 mooring site (Fig. 5). We considered the portion of the tracks within the rectangle in Fig. 5, and computed the surface geostrophic velocity associated with each crossing (using the component of velocity in the crosstrack direction). Following this, we constructed composites of the surface velocity for each day of the flooding events, covering a \pm 3 day period centered on the peak of the event. The times of the events were identified from the mooring data.

This calculation reveals that the flooding events are indeed associated with a westward propagation of the NIIC (Fig. 6a). Prior to the event the NIIC is located over the outer Iceland slope and the velocity is equatorward in the trough. As the event progresses, the NIIC moves across the strait at a rate of $\sim 20 \mathrm{~km} \mathrm{day}^{-1}$ (indicated by the dashed line in Fig. 6a). At the end of the event the surface velocity at the DS1 site becomes equatorward again, consistent with the mooring data. The northwardflowing NIIC is also reestablished over the Iceland slope.

This sequence is confirmed using independent SST satellite data from MODIS. We constructed the analogous composite of the SST gradient across the strait near the mooring location (Fig. 6b). Although the SST signature is more noisy than the ADT signal, the NIIC is clearly identifiable as a maximum in SST gradient, that is, the hydrographic front of the warm, salty Irminger water. One sees that the front propagates westward in conjunction with the surface velocity signal during the flooding event at the same rate of $20 \mathrm{~km} \mathrm{day}^{-1}$. The extent of the frontal excursion is consistent with that deduced from the time
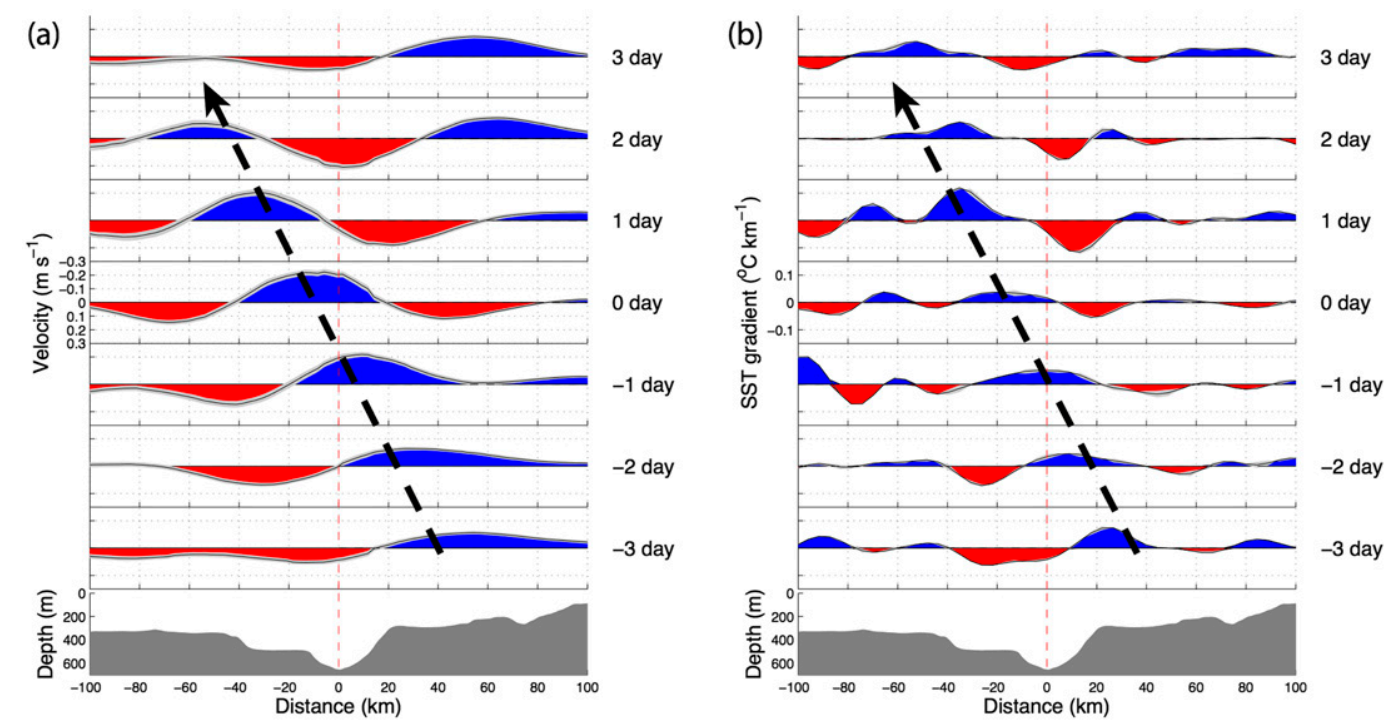

FIG. 6. (a) Composite along-strait surface geostrophic velocity during a flooding event. Blue is poleward and red is equatorward. Day 0 corresponds to the peak of the event, defined using the DS1 mooring data. The dashed black arrow denotes the westward propagation of the NIIC. The bottom panel shows the cross-strait bathymetry. The red dashed line marks the location of the DS1 mooring. (b) Composite of the cross-strait SST gradient during a flooding event. The positive gradient associated with the NIIC (large blue peak) propagates westward at the same speed as the surface geostrophic velocity signal in (a), indicated by the identical dashed black arrow. 
integral of the depth-mean cross-stream velocity of the upper layer using the mooring data (roughly $40 \mathrm{~km}$, see Fig. 4e). ${ }^{1}$

\section{c. Relationship of flooding events to pulses}

As described by von Appen et al. (2017), the pulses in Denmark Strait are associated with an increased equatorward flow of DSOW in concert with a change in crossstream velocity from negative to positive; that is, prior to the pulse the cross-streamflow is toward Greenland, and subsequent to the pulse it is toward Iceland, resulting in an anticyclonic sense of rotation. Throughout the event the cross-stream velocity signal is surface intensified. At the same time, the NIIC hydrographic front is displaced westward during a pulse. This led von Appen et al. (2017) to hypothesize that the occurrence of pulses was dynamically related to the behavior of the NIIC.

In the composite flooding event of Fig. 4, the alongstream velocity in the overflow experiences a temporary peak roughly one day after the temperature peak. In addition, the cross-stream velocity in the water column above the overflow changes sign such that, prior to the alongstream peak, the upper-layer flow is toward Greenland, while afterward it is toward Iceland. Furthermore, the overflow interface height decreases during this sequence of events. ${ }^{2}$ The combination of these signals is strikingly reminiscent of the pulses described by von Appen et al. (2017, see their Fig. 9). Our analysis thus implies that flooding events are in fact related to pulses and do not represent a different type of mesoscale process in Denmark Strait.

We note that not every flooding event detected by the DS1 mooring was followed by a pulse. One possible explanation for this is that, for especially strong flooding events (associated with pronounced excursions of the NIIC), the subsequent pulse occurred to the west of the mooring location. This is consistent with the fact that these events were associated with warmer bottom temperatures. Nonetheless, the majority of the flooding events were followed by a pulse (as is evident from the composite of Fig. 4). However, the opposite is not true. The mooring data indicate that not all pulses are preceded by warm water flooding the deepest part of the trough. In fact, there are many more pulses than there are flooding events. von Appen et al. (2017) determined that pulses occur on average every 5.4 days, whereas

\footnotetext{
${ }^{1}$ It is unclear why the surface signature of the NIIC does not appear to propagate back to the east after the flooding event.

${ }^{2}$ When the bottom temperature is above $0^{\circ} \mathrm{C}$ there is no overflow water present, and, consequently, there is no interface between the overflow layer and the water above. This explains the gap in the interface time series.
}

flooding events take place roughly once a month (Fig. 3b). The likely explanation for this is that flooding events measured by the mooring are simply cases when the NIIC is displaced far enough westward to reach the mooring site in the trough. This is supported by the numerical model results presented below.

\section{Frontogenesis}

We now focus on the structure of the boundary current system in the vicinity of Denmark Strait using the model data. Consider first a meridional section at $25.75^{\circ} \mathrm{W}$, north of the Latrabjarg line (the section is shown in Fig. 7d). The three major currents near the Iceland slope are evident: the Separated EGC, the NIJ, and the NIIC (Fig. 7a, the former two are in the process of merging at this point). The middepth maximum in the southwestward-flowing NIJ is supported by the change in slope of the isopycnals around $500-\mathrm{m}$ depth. The northeastward-flowing NIIC is strongest near the bottom, with the vertical shear balanced by the upward sloping isopycnals near the surface. The temperature and salinity sections delineate the different water masses transported by these three velocity cores (Figs. 7b,c). The water in the NIIC is warm and salty, while the overflow water in the NIJ is colder and slightly fresher. The near-surface portion of the Separated EGC transports a combination of cold and very fresh polar water alongside Atlantic water. In the upper part of the water column the density is controlled by salinity, while near the bottom it is controlled by temperature.

\section{a. Energetics}

The eddy kinetic energy at 50- and at 420-m depth are shown in Fig. 8. Eddies here are defined as deviations from the time mean fields so include variability at all frequencies less than 1 year. At both levels local maxima of $O(0.1) \mathrm{m}^{2} \mathrm{~s}^{-2}$ are found near and south of the Denmark Strait sill. This is larger than the estimate by Håvik et al. (2017) of $0.02 \mathrm{~m}^{2} \mathrm{~s}^{-2}$, which was based on along-track sea surface height satellite measurements and is thus probably an underestimate due to limited spatial and temporal resolution of the data. The upper layer shows a band of enhanced variability extending to the northeast while the deeper level is enhanced to the southwest. There is also enhanced eddy kinetic energy over the shelf west of Denmark Strait, which is a distinct feature and will not be discussed further. The dominant variability lies along the 600-m isobath both to the northeast and southwest of Denmark Strait.

The correlation between the high-frequency temperature variability at $50-\mathrm{m}$ depth and that at $420-\mathrm{m}$ depth is shown in Fig. 9. The time series of temperature 

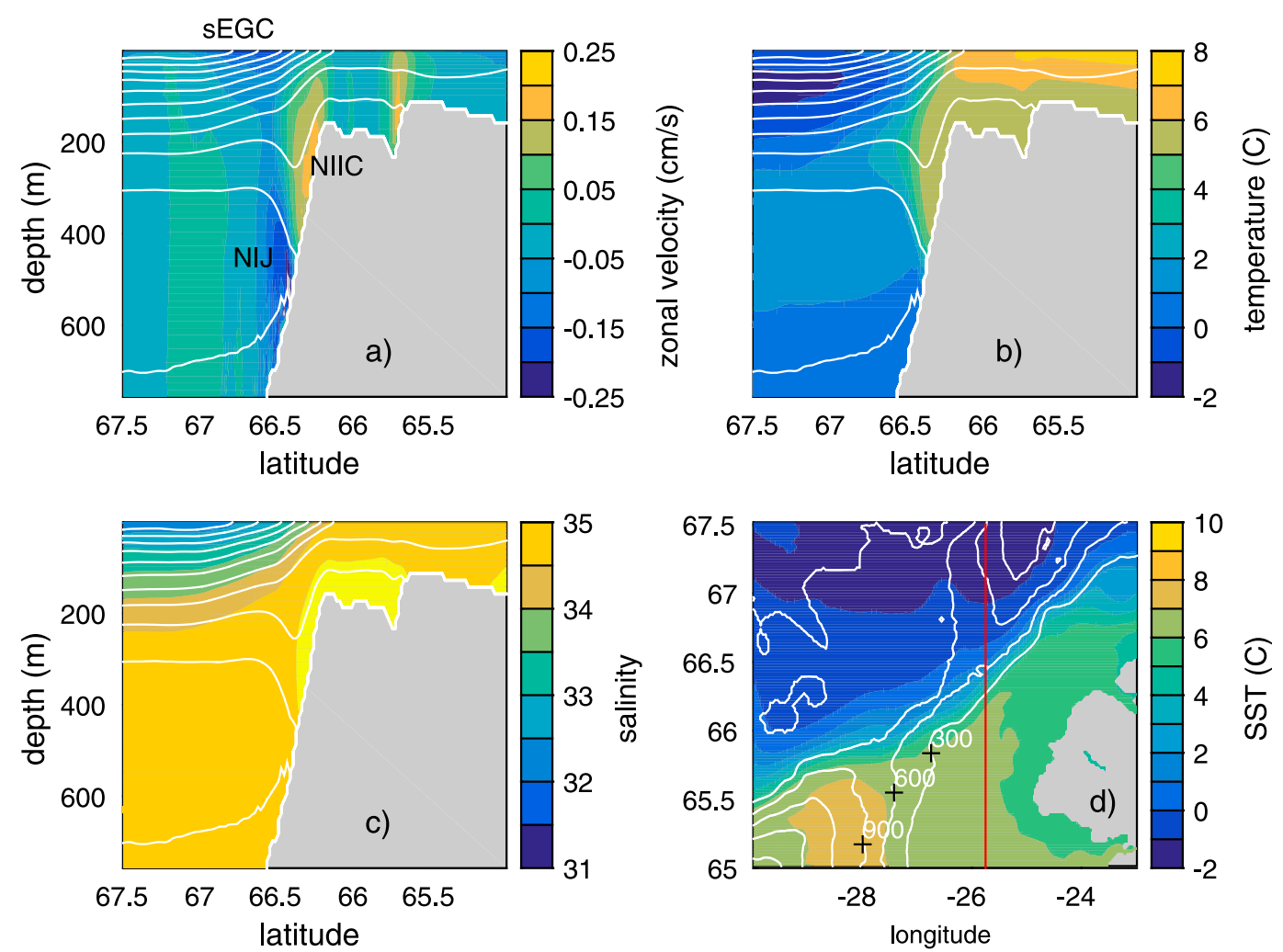

FIG. 7. Meridional section of the mean (a) zonal velocity $\left(\mathrm{m} \mathrm{s}^{-1}\right),(\mathrm{b})$ temperature $\left({ }^{\circ} \mathrm{C}\right)$, and (c) salinity. The white contours are potential density, with a contour interval of $0.2 \mathrm{~kg} \mathrm{~m}^{-3}$. (d) Mean sea surface temperature. The white contours are bottom topography (contour interval is $300 \mathrm{~m}$ ), and the red line marks the location of the meridional sections in (a)-(c).

at each grid point has been high-pass filtered for periods less than 10 days to highlight the vertical coherence of the mesoscale variability and filter out seasonal and lower frequency influences. The correlation was computed at zero time lag; positive and negative time lags between the shallow and deep time series produce lower correlations. There is a band of high correlation (exceeding 0.8) extending from Denmark Strait to the southwest. This is the signal of the strong cyclones that are known to be generated due to the descending overflow of dense water south of the strait (Smith 1976; Spall and Price 1998; Käse et al. 2003). This is also reflected in the eddy kinetic energy fields. However, the correlation northeast of the strait is much lower even though the near-surface kinetic energy there is similar to that found southwest of the strait.

The energy source of the variability in the vicinity of Denmark Strait is now diagnosed. Sources due to internal instabilities are characterized as either baroclinic or barotropic, depending on whether the eddy energy is derived from the mean potential energy $(\mathrm{BC}=$ baroclinic $)$ or the mean kinetic energy $(\mathrm{BT}=$ barotropic). The energy conversion rates are calculated as

$$
\begin{aligned}
& \mathrm{BC}=-g / \rho_{0}\left(\gamma_{x} \overline{u^{\prime} \sigma_{\theta}^{\prime}}+\gamma_{y} \overline{v^{\prime} \sigma_{\theta}^{\prime}}\right), \\
& \mathrm{BT}=-\overline{u^{\prime} v^{\prime}}\left(\bar{u}_{y}+\bar{v}_{x}\right),
\end{aligned}
$$

where $u$ and $v$ are the zonal and meridional velocities, overbars indicate the time average, $\sigma_{\theta}$ is the potential density, primes are deviations from the time mean, $g$ is gravitational acceleration, and $\rho_{0}$ is a reference density. Mean potential energy is converted to eddy energy by the horizontal eddy density flux in the direction of the mean isopycnal slope, where $\gamma_{x}$ and $\gamma_{y}$ are the isopycnal slopes in the zonal and meridional directions (BC). Mean kinetic energy is converted to eddy energy by the eddy momentum flux $\overline{u^{\prime} v^{\prime}}$ across the mean horizontal velocity shear $\bar{u}_{y}+\bar{v}_{x}(\mathrm{BT})$. Positive values indicate a transfer of energy from the mean fields to the eddy fields.

The baroclinic conversion rates at $420-$ and $50-\mathrm{m}$ depth are shown in Figs. 10a and 10b. At depth there is energy extraction from the mean in a band extending from the sill toward the southwest, along the path of the 

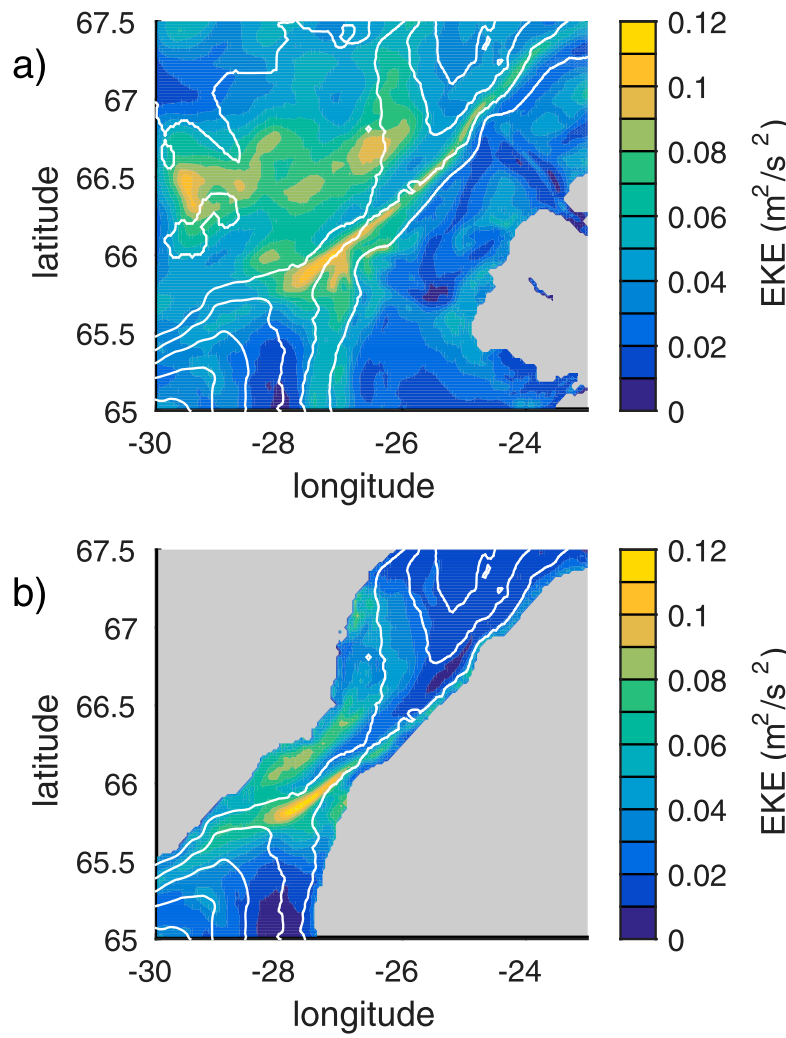

FIG. 8. Eddy kinetic energy at (a) 50- and (b) 420-m depth $\left(\mathrm{m}^{2} \mathrm{~s}^{-2}\right)$. Bottom topography is indicated by the white contours (contour interval is $300 \mathrm{~m}$ ).

overflow water. At 50-m depth there is also a positive conversion, although it is more spatially variable and largest from the sill toward the northeast, along the path of the NIIC. Both baroclinic instability and symmetric instability result in $\mathrm{BC}>0$, but the conditions for symmetric instability-that Ertel potential vorticity be negative-are not satisfied outside of $O(10)$ m thick surface and bottom boundary layers. Hence we attribute the source of the variability to baroclinic instability of both the dense overflow waters and the NIIC. The NIJ does not exhibit significant energy conversion upstream of the sill even though there is baroclinic shear present. The energy conversion terms and vertical coherence suggest that two distinct forms of variability are present: a coupled mode in and south of the strait, and a surface intensified mode in the NIIC along the northwest Iceland shelf break.

The vertical structure of $\mathrm{BC}$ and along-strait velocity at the sill are shown in Figs. 10c and 10d for the model equivalent of the Látrabjarg transect (red line in Figs. 10a,b). There are two cores of energy conversion, one near the bottom and one near the surface. The bottom region is extracting energy from the sloped isopycnals associated with the weakly stratified, dense overflow water. The

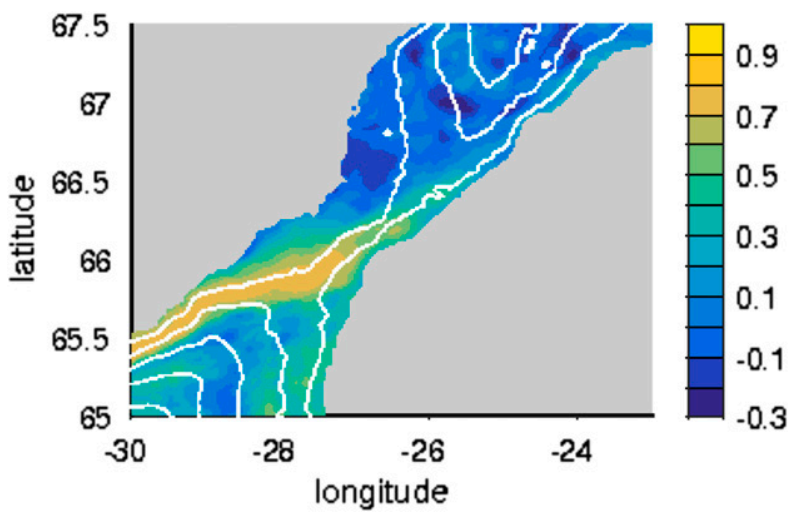

FIG. 9. Correlation between the temperature anomaly at 50-m depth and the temperature anomaly at 420-m depth. Bottom topography is indicated by the white contours (contour interval is $300 \mathrm{~m}$ ).

upper region is extracting energy from the density gradient between the lighter southward-flowing water in the Separated EGC and denser northward-flowing water in the NIIC. The isopycnals are relatively flat in the middle of the water column and so provide little source for energy extraction there. The barotropic conversion term BT was also calculated but was found to be generally much smaller, especially when integrated across the current because there are regions of offsetting positive and negative eddy momentum fluxes. The Reynolds stresses act primarily to shift the location of the front slightly.

\section{b. Temperature and salinity balances}

The variability associated with the baroclinic conversion term acts to relax the isopycnal slopes. In terms of the temperature tendency equation, this causes the warm side of the front to cool and the cold side of the front to warm. The contribution to the tendency of temperature and salinity by the mean and the negative of the eddy advection terms ${ }^{3}$ at 50-m depth are shown in Fig. 11. The mean advection is making the northwest side of the front colder and fresher and the southeast side warmer and saltier. The eddy advection terms generally counteract the mean flow, making the northwest side of the front warmer and saltier and the southeast side colder and fresher. Although there is some spatial variability, this general balance is found all along the frontal region.

A similar balance is found at all depths north of Denmark Strait. This is seen in the vertical sections of temperature and salinity tendency for the transect along $27.75^{\circ} \mathrm{W}$ (Fig. 12). Although the balance is not exact, to leading order the flow is adiabatic with the mean flow acting to increase the lateral temperature and

\footnotetext{
${ }^{3}$ The negative is shown in order to make it easier to compare with the mean.
} 

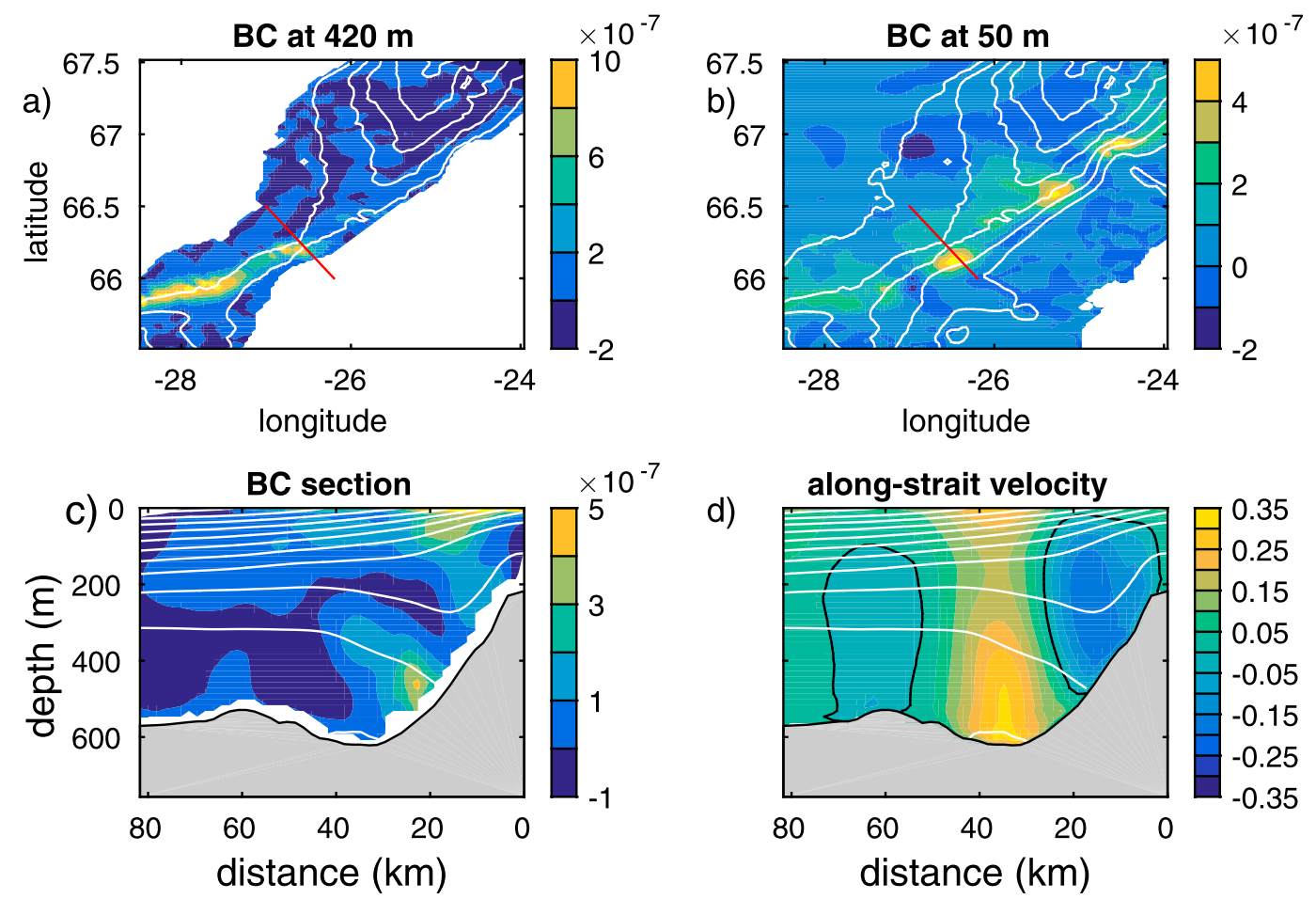

FIG. 10. Baroclinic energy conversion rate BC at (a) 420- and (b) 50-m depth $\left(\mathrm{m}^{2} \mathrm{~s}^{-3}\right.$ ). (c) Vertical section of BC along the red line in (a) and (b). (d) Time-mean velocity normal to the section ( $\mathrm{m} \mathrm{s}^{-1}$; zero contour is black; distance is in $\mathrm{km}$ from southeast to northwest; positive is flow toward the southwest). The white contours in (c) and (d) are potential density (contour interval is $0.2 \mathrm{~kg} \mathrm{~m}^{-3}$ ).

salinity gradients and the eddies acting to weaken the front. Note that the isopycnal slope changes sign with depth. Therefore, in the upper ocean the mean advection of salinity is acting to increase the horizontal density gradient, while at depth the advection of temperature is acting to increase the horizontal density gradient.

The mean model SST and surface velocity field in the region encompassing Denmark Strait are shown in Fig. 13a. This reveals the convergent mean flow that supports the hydrographic front: cold, fresh surface waters are advected from the north, and warm, salty surface waters are advected from the south. The analogous fields derived from the satellite ADT and SST data are shown in Fig. 13b. While the model produces a sharper temperature front, likely due to the coarser resolution and processing of the satellite data, the overall surface velocity and temperature fields are very similar between the model and observations. It is noteworthy that the mean velocity field at the surface is broadly distributed across the strait; it is not confined to narrow boundary currents. Its significant orthogonal relationship with surface density (and temperature and salinity) gradients points to the importance of the barotropic component of the flow.

A measure of the influence of the mean flow on the tracer fields is given by the strain field $\varepsilon$, defined as

$$
\varepsilon=\left[\left(u_{x}-v_{y}\right)^{2}+\left(v_{x}+u_{y}\right)^{2}\right]^{1 / 2},
$$

where subscripts indicate partial differentiation and $u$, $v$ are the mean velocities. As seen in Fig. 13c, the timemean model strain is largest along the boundary between waters emanating from the north and those originating from the south. ${ }^{4}$ It is clear that the mean velocity acts to increase the horizontal gradient of temperature along this boundary (also the gradients of salinity and density). The strain calculated from the satellite-derived velocity field (Fig. 13d) shows a similar pattern with a maximum along the temperature front northeast of Denmark Strait (the magnitude is smaller, which is expected given the low resolution of the gridded velocity field). Interestingly, calculation of the strain over the Faroe Bank overflow region does not show a similar enhancement; this appears to be unique to the Denmark Strait. This is likely because Denmark Strait lies on the western boundary of the Nordic Seas and is thus the location of southwardflowing, low-salinity waters, and the topographic configuration

\footnotetext{
${ }^{4}$ There is also very large strain over the Djupall Canyon near $66.5^{\circ} \mathrm{N}, 24^{\circ} \mathrm{W}$, perhaps also weakly present in the satellite data.
} 

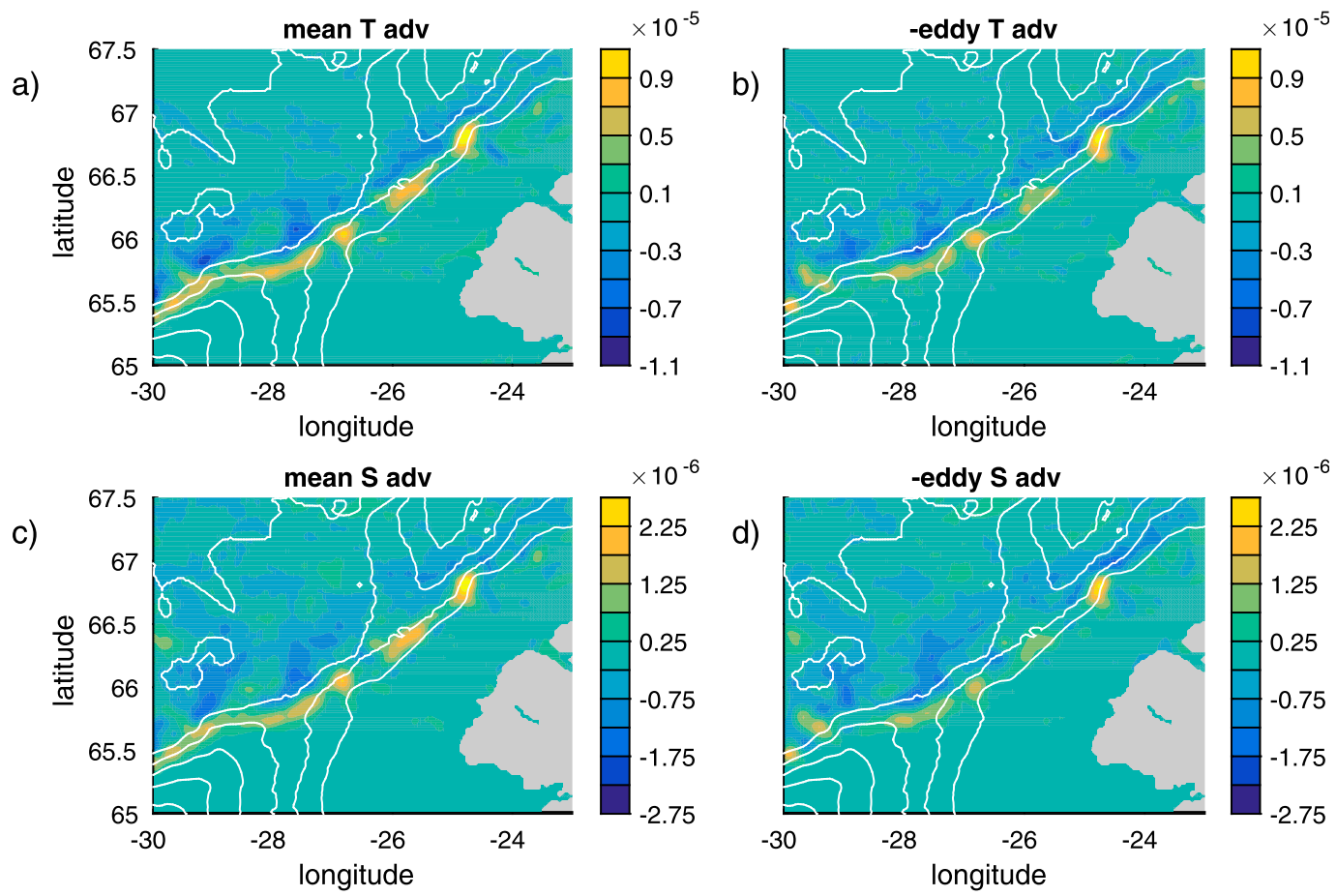

FIG. 11. Contributions to the temperature $\left({ }^{\circ} \mathrm{Cs}^{-1}\right)$ and salinity $\left(\mathrm{s}^{-1}\right)$ tendency equations at $50-\mathrm{m}$ depth due to (a) mean temperature advection, (b) negative of the eddy temperature advection, (c) mean salinity advection, and (d) negative of the eddy salinity advection.

steers the northward- and southward-flowing waters through the narrow strait. These waters were identified as a key driver of the cyclogenesis south of Denmark Strait by Spall and Price (1998).

Eddy fluxes play a leading role in the temperature, salinity, and density budgets by acting to adiabatically balance the mean flow. This is important because, if the eddy field is not sufficiently resolved, the mean flow will collapse the gradients to such small scales that parameterized or numerical lateral mixing will become important (Spall 1997; McWilliams and Molemaker 2011). Such subgrid-scale mixing often artificially introduces diapycnal mixing, modifying the water masses and the resulting transports of heat and salt.

\section{c. Relation to overflow water variability}

Returning to the short-time-scale variations of the DSOW, we are now in a better position to understand the underlying cause of these fluctuations and relate the boluses and pulses to each other (it has already been demonstrated that flooding events are extreme versions of pulses). The model has revealed that the NIIC is baroclinically unstable. A manifestation of this is the meandering of the hydrographic front (akin to the Gulf Stream north wall). When flooding events are present, meanders of the NIIC projected onto the nearly zonal satellite tracks in Fig. 5 produce a zonal phase speed of approximately $20 \mathrm{~km} \mathrm{day}^{-1}$ to the west, very close to the satellite observations (see Fig. 6). The meandering results in enhanced eddy kinetic energy at periods of several days, consistent with the observed overflow variability measured at the sill.

Using the model fields we composited the SST during periods when flooding events were present at the sill and periods when boluses of DSOW were present at the sill. Flooding events were defined as times when the temperature at 600-m depth was warmer than $3^{\circ} \mathrm{C}$ and boluses were defined as times when the temperature at $400-\mathrm{m}$ depth was colder than $1^{\circ} \mathrm{C}$. While these definitions differ slightly from those used above for the mooring, the model provides more information in the vertical and these choices allow for a clearer identification of these events. As seen in Fig. 14, flooding events occur during meander crests (northwestward excursions of the NIIC front), while boluses occur during meander troughs (southeastward excursions of the NIIC front). This is consistent with respect to the observed lateral movement of the front during pulses (von Appen et al. 2017) and during flooding events (Fig. 6). [There is no observational evidence to date of shoreward excursions of the NIIC during boluses, mainly because of a seasonal bias in the collection of Látrabjarg transects, see von Appen et al. (2017). However, in the 

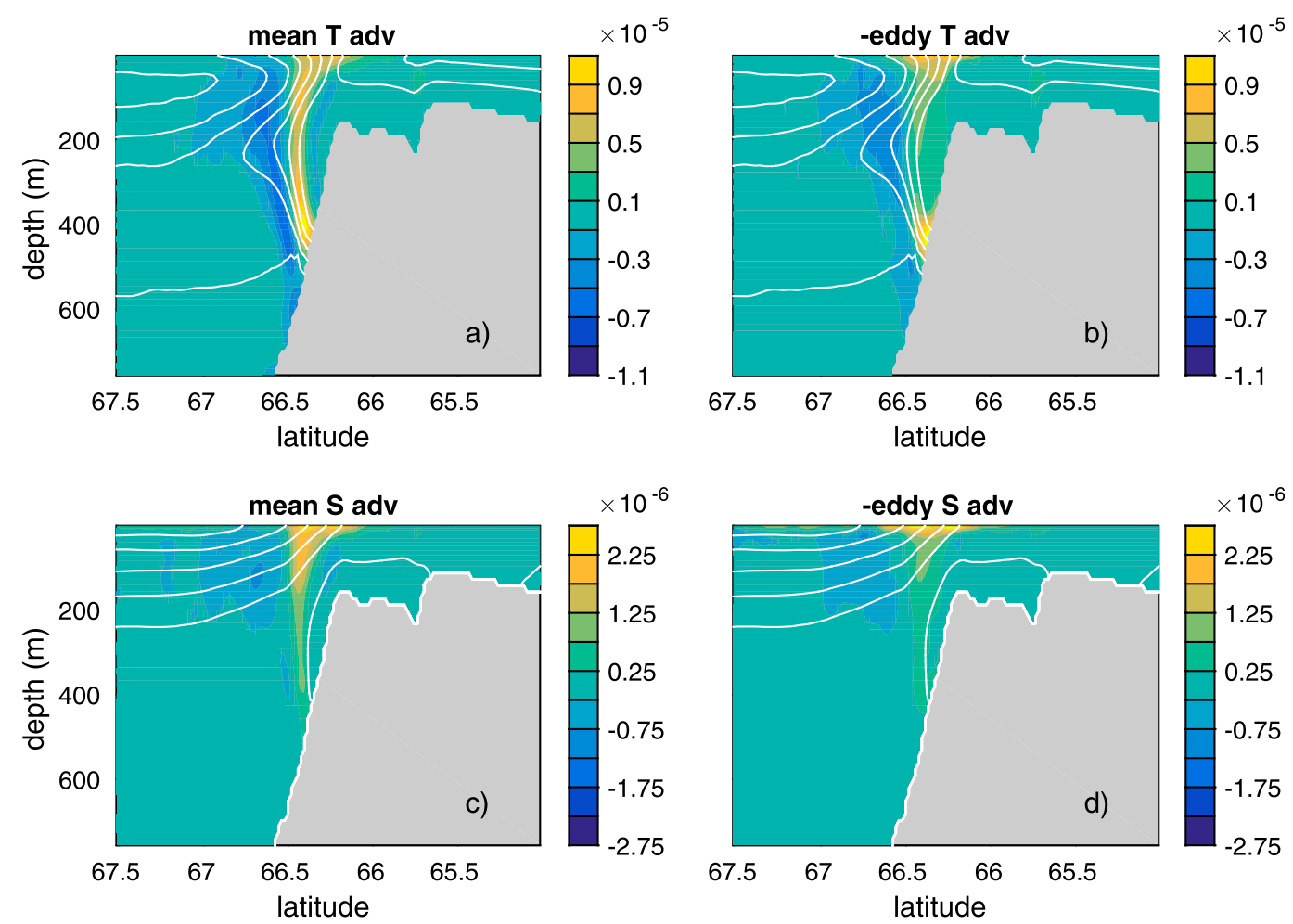

FIG. 12. Contributions to the temperature and salinity tendency equations across the meridional section at $25.75^{\circ} \mathrm{W}$ (see Fig. $7 \mathrm{~d}$ ) due to (a) mean temperature advection, (b) negative of the eddy temperature advection, (c) mean salinity advection, and (d) negative of the eddy salinity advection. The white contours are for temperature in (a) and (b) (contour interval is $1^{\circ} \mathrm{C}$ ) and salinity in (c) and (d) (contour interval is 0.5 ).

model of Almansi et al. (2017) the NIIC moved onshore during bolus events.] The observed cyclonic versus anticyclonic sense of rotation of the boluses versus pulses is also consistent with the meander troughs versus crests seen in the model composites. These results thus link the two dominant modes of observed overflow variability to a single dynamical process associated with the instability of the hydrographic front in Denmark Strait.

\section{Discussion and summary}

In situ observations, remotely sensed data, and a regional high-resolution numerical model have been used to provide a unifying view of high-frequency variability in the vicinity of Denmark Strait. The observed flooding of warm, salty northward-flowing water through the deepest part of the strait is shown to be associated with a westward shift of the NIIC. These flooding events occur about once per month and appear to be extreme versions of the more common and previously described anticyclonic pulses of dense water.

It was also shown that the front separating the northwardflowing NIIC from the southward-flowing Separated EGC/ NIJ (which are essentially merged in the strait) is baroclinically unstable. There are two dominant regions of energy conversion which act to flatten the isopycnals: one in the upper layer and one near the bottom. The large-scale mean flow in both the numerical model and that inferred from sea surface height data are broadly southward-flowing north of the sill and northward-flowing south of the sill. The water north of the sill is cold and fresh while the water south of the sill is warm and salty. This provides a confluent flow that acts to sharpen the horizontal gradients of temperature and salinity, and to steepen the isopycnals throughout the water column. Over the long-term mean, the tendency of the mean flow to steepen the front is nearly adiabatically balanced by the tendency for eddies generated by baroclinic instability to relax the front. Thus we view the highfrequency (from one day to one week) variability in the vicinity of Denmark Strait to derive from a baroclinic front maintained locally by the large-scale mean flow. Similar balances between confluent flows and frontal instability have been discussed in the context of submesoscale upperocean fronts (Spall 1997; McWilliams and Molemaker 2011).

Our results suggest that the intense growth of cyclones southwest of the sill results at least in part from the localization of the confluent flow in the vicinity of the sill. Once the strong baroclinic shear that is formed 

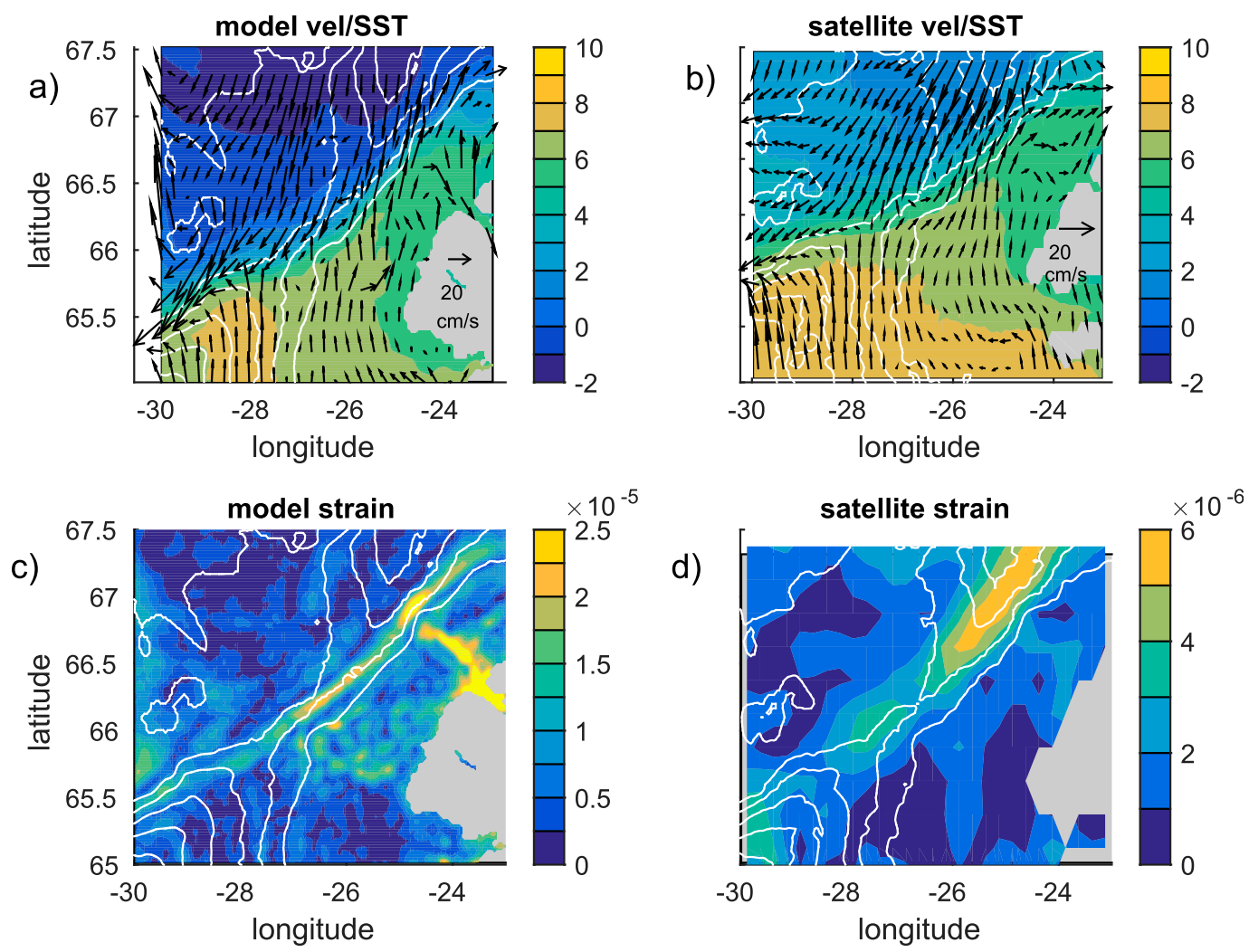

FIG. 13. (a) Mean velocity and SST from the model. (b) As in (a), but calculated using the satellite data. (c) Mean strain field from the model $\left(\mathrm{s}^{-1}\right)$. (d) As in (c), but using the satellite derived surface velocity.

near the sill is free from the frontogenetic effect of the large-scale mean flow, baroclinic instability can grow unchecked. The growth rate is likely also enhanced by the large horizontal gradients in potential vorticity found south of the sill (Spall and Price 1998). A similar, but weaker, region of baroclinic conversion is found in the upper ocean to the northeast of the sill. There does not appear to be an analogous confluence flow in the vicinity of the Faroe Bank overflow or the Mediterranean overflow, but there is a similar confluence with strong fronts and enhanced eddy variability in Fram Strait (Hattermann et al. 2016).

This highlights the importance of properly representing both baroclinic instability and eddy fluxes on small scales. If a model is unable to represent the energy conversion and growth of eddies and meanders, it will not be able to properly arrest the frontogenetic effect of the confluent flow. Eventually the front will sharpen a)

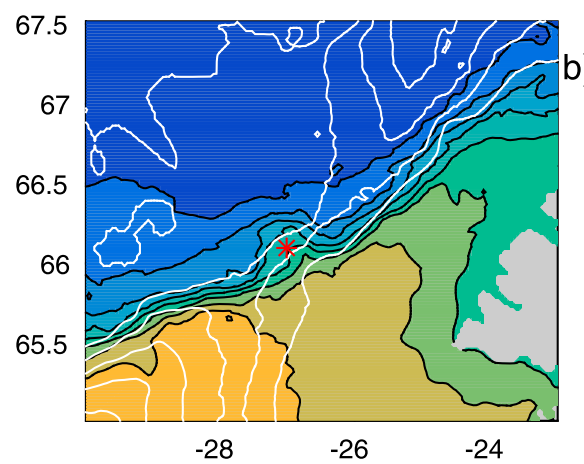

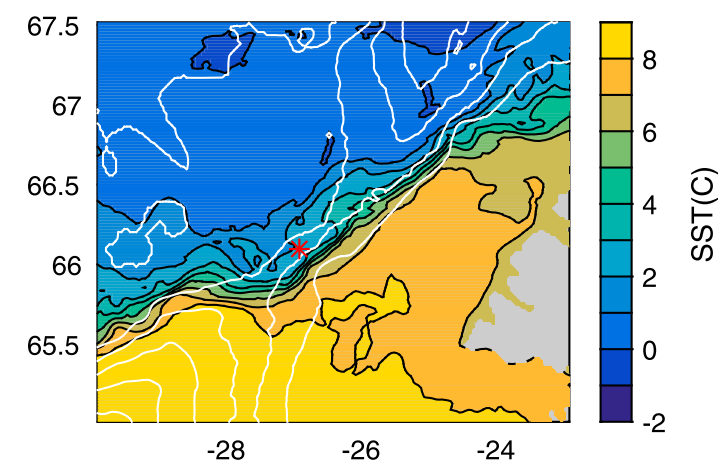

FIG. 14. Composite averages of SST from the model for (a) periods when flooding events were present and (b) periods when DSOW boluses were present. White contours are bottom topography (contour interval is $300 \mathrm{~m}$ ). The red asterisk is the location of the mooring. 
to the point where numerical mixing balances the mean flow. This will introduce diapycnal mixing that dilutes the water masses, both those flowing northward into the Nordic Seas and those flowing southward forming the headwaters of the Deep Western Boundary Current. In addition to producing water masses of incorrect density, this mixing will alter the heat and freshwater transports associated with the AMOC. This is analogous to the "Veronis Effect" (Veronis 1975), previously identified as a major source of error in the meridional heat transport in climate models that results from numerical diapycnal mixing in the vicinity of the Gulf Stream.

Acknowledgments. MAS was supported by the National Science Foundation (NSF) under Grants OCE-1558742 and OCE-1534618. RSP, PL, and DM were supported by NSF under Grants OCE-1558742 and OCE-1259618. WJvA was supported by the Helmholtz Infrastructure Initiative FRAM. TWNH and MA were supported by NSF under Grants OCE-1633124 and OCE-118123.

\section{REFERENCES}

Aagaard, K. and S.-A. Malmberg, 1978: Low-frequency characteristics of the Denmark Strait overflow. ICES CM 1978/C:47, International Council for the Exploration of the Sea, Copenhagen, Denmark, 22 pp.

Almansi, M., T. W. N. Haine, R. S. Pickart, M. G. Magaldi, R. Gelderloos, and D. Mastropole, 2017: High-frequency variability in the circulation and hydrography of the Denmark Strait overflow from a high-resolution numerical model. J. Phys. Oceanogr., 47, 2999-3013, https://doi.org/10.1175/JPO-D-17-0129.1.

Cooper, L. H. N., 1955: Deep water movements in the North Atlantic as a link between climatic changes around Iceland and biological productivity of the English Channel and Celtic Sea. J. Mar. Res., 14, 347-362.

Dee, D. P., and Coauthors, 2011: The era-interim reanalysis: Configuration and performance of the data assimilation system. Quart. J. Roy. Meteor. Soc., 137, 553-597, https://doi.org/ 10.1002/qj.828.

Dickson, R. R., and J. Brown, 1994: The production of North Atlantic Deep Water: Sources, rates and pathways. J. Geophys. Res., 99, 12 319-12341, https://doi.org/10.1029/94JC00530.

Fristedt, T., R. Hietala, and P. Lundberg, 1999: Stability properties of a barotropic surface-water jet observed in the Denmark Strait. Tellus, 51, 979-989, https://doi.org/10.3402/ tellusa.v51i5.14506.

Harden, B., and Coauthors, 2016: Upstream sources of the Denmark Strait overflow: Observations from a high-resolution mooring array. Deep-Sea Res. I, 112, 94-112, https://doi.org/10.1016/j.dsr.2016.02.007.

Hattermann, T., P. E. Isachsen, W.-J. von Appen, J. Albretsen, and A. Sundfjord, 2016: Eddy-driven recirculation of Atlantic Water in Fram Strait. Geophys. Res. Lett., 43, 3406-3414, https://doi.org/10.1002/2016GL068323.

Håvik, L., K. Våge, R. S. Picakrt, B. Harden, W.-J. von Appen, S. Jósson, and S. Østerhus, 2017: Structure and variability of the Shelfbreak East Greenland Current north of Denmark Strait. J. Phys. Oceanogr., 47, 2631-2646, https://doi.org/ 10.1175/JPO-D-17-0062.1.
Jochumsen, K., D. Quadfasel, H. Valdimarsson, and S. Jónsson, 2012: Variability of the Denmark Strait overflow: Moored time series from 1996-2011. J. Geophys. Res., 117, https:// doi.org/10.1029/2012JC008244.

_, M. Moritz, N. Nunes, D. Quadfasel, K. Larsen, B. Hansen, H. Valdimarsson, and S. Jonsson, 2017: Revised transport estimates of the Denmark Strait Overflow. J. Geophys. Res., 122, 3434-3450, https://doi.org/10.1002/2017JC012803.

Käse, R. H., J. B. Girton, and T. B. Sanford, 2003: Structure and variability of the Denmark Strait overflow: Model and observations. J. Geophys. Res., 108, 3181, https://doi.org/10.1029/ 2002JC001548.

Macrander, A., R. H. Käse, U. Send, H. Valdimarsson, and S. Jonsson, 2007: Spatial and temporal structure of the Denmark Strait Overflow revealed by acoustic observations. Ocean Dyn., 57, 75-89, https://doi.org/10.1007/s10236-007-0101-x.

Marshall, J., C. Hill, L. Perelman, and A. Adcroft, 1997: Hydrostatic, quasi-hydrostatic, and non-hydrostatic ocean modeling. J. Geophys. Res., 102, 5733-5752, https://doi.org/10.1029/96JC02776.

Mastropole, D., R. S. Pickart, H. Valdimarsson, K. Våge, K. Jochumsen, and J. Girton, 2017: On the hydrography of Denmark Strait. J. Geophys. Res. Oceans, 122, 306-321, https://doi.org/10.1002/2016JC012007.

Mauritzen, C., 1996: Production of dense overflow waters feeding the North Atlantic across the Greenland-Scotland Ridge. Part 1: Evidence for a revised circulation scheme. Deep-Sea Res. I, 43, 769-806, https://doi.org/10.1016/0967-0637(96)00037-4.

McWilliams, J. C., and J. Molemaker, 2011: Baroclinic frontal arrest: A sequel to unstable frontogenesis. J. Phys. Oceanogr., 41, 601-619, https://doi.org/10.1175/2010JPO4493.1.

Nikolopoulos, A., K. Borenas, R. Hietala, and P. Lundberg, 2003: Hydraulic estimates of Denmark Strait overflow. J. Geophys. Res., 108, 3095, https://doi.org/10.1029/2001JC001283.

Pawlowicz, R., R. Beardlsey, and S. Lentz, 2002: Classical tidal harmonic analysis including error estimates in MATLAB using T_TIDE. Comput. Geosci., 28, 929-937, https://doi.org/ 10.1016/S0098-3004(02)00013-4.

Pickart, R., M. Spall, D. Torres, K. V. H. Valdimarsson, C. Nobre, G. Moore, S. Jonsson, and D. Mastropole, 2017: The North Icelandic Jet and its relationship to the North Icelandic Irminger Current. J. Mar. Res., 75, 605-639, https://doi.org/10.1357/ 002224017822109505.

Ross, C., 1978: Overflow water variability in Denmark Strait. ICES J. Mar. Sci., 21, 1-9.

Smith, P. C., 1976: Baroclinic instability in the Denmark Strait overflow. J. Phys. Oceanogr., 6, 355-371, https://doi.org/10.1175/ 1520-0485(1976)006<0355:BIITDS > 2.0.CO;2.

Spall, M. A., 1997: Baroclinic jets in confluent flow. J. Phys. Oceanogr., 27, 1054-1071, https://doi.org/10.1175/1520-0485(1997)027<1054: $\mathrm{BJICF}>2.0 . \mathrm{CO} ; 2$.

_ , and J. F. Price, 1998: Mesoscale variability in Denmark Strait: The PV outflow hypothesis. J. Phys. Oceanogr., 28, 1598-1623, https://doi.org/10.1175/1520-0485(1998)028<1598:MVIDST> 2.0.CO;2.

Våge, K., R. S. Pickart, M. A. Spall, H. Valdimarsson, S. Jónsson, D. J. Torres, S. Østerhus, and T. Eldevik, 2011: Significant role of the North Icelandic Jet in the formation of Denmark Strait overflow water. Nat. Geosci., 4, 723-727, https://doi.org/10.1038/ ngeo1234.

, R. Pickart, M. Spall, G. Moore, H. Valdimarsson, D. Torres, S. Erofeeva, and J. Nilsen, 2013: Revised circulation scheme north of the Denmark Strait. Deep-Sea Res. I, 79, 20-39, https://doi.org/10.1016/j.dsr.2013.05.007. 
— G. Moore, S. Jonsson, and H. Valdimarsson, 2015: Water mass transformation in the Iceland Sea. Deep-Sea Res. I, 101, 98-109, https://doi.org/10.1016/j.dsr.2015.04.001.

Veronis, G., 1975: The role of models in tracer studies. Numerical Models of the Ocean Circulation, National Academy of Sciences, 133-146.

von Appen, W.-J., D. Mastropole, R. S. Pickart, H. Valdimarsson, S. Jonsson, and J. Girton, 2017: On the nature of the mesoscale variability in Denmark Strait. J. Phys. Oceanogr., 47, 567-582, https://doi.org/10.1175/JPO-D-16-0127.1.

Whitehead, J., 1989: Internal hydraulic control in rotating fluids Applications to oceans. Geophys. Astrophys. Fluid Dyn., 48, 169-192, https://doi.org/10.1080/03091928908219532.

A. Leetmaa, and R. Knox, 1974: Rotating hydraulics of strait and sill flows. Geophys. Fluid Dyn., 6, 101-125, https://doi.org/ 10.1080/03091927409365790. 